\title{
Effects of Global Warming Simulated Temperature and Water Stress on Fruit Quality of Tomato (Lycopersicum esculantum) Var. Rajitha
}

\author{
M. D. M Gunawardena and C. S. De Silva* \\ Department of Agricultural and Plantation Engineering, The Open \\ University of Sri Lanka
}

\begin{abstract}
Experiments were conducted in the temperature regulated polytunnels for five consecutive growing seasons at the Open University of Sri Lanka to evaluate the impact of the enhanced temperature and water stress due to Global warming on marketable fruit quality. Split plot experiment based on complete randomized design with 10 replicates was applied as experimental design. The plants were grown in pots, and the main plot included two moisture levels (No water stress, $50 \%$ water stress from the field capacity) and sub plots contained 3 different temperature regimes $\left(34^{\circ} \mathrm{C}\right.$ maximum temperature $/ 32^{\circ} \mathrm{C}$ maximum temperature / ambient temperature). Experiments were repeated for 3 seasons to replicate temperature effect. The combination effect of water stress and temperature stress proved to be a significant drawback for tomato yield and marketable fruit quality such as colour, shape, soluble solids content, $\mathrm{pH}$ and sugar acid ratio. Mealy bug attack too was very significant in high temperature poly tunnel experiment which affected the marketable fruit quality. Therefore, tomato variety Rajitha could not be a successful open field crop in the dry zone of Sri Lanka if temperature is increased due to global warming. But tomato could be cultivated under green houses by providing adequate water and required soil temperature.
\end{abstract}

* Correspondence should be addressed to Prof. C. S. De Silva, Department of Agricultural and Plantation Engineering, The Open University Sri Lanka, Nawala, Sri Lanka (Email: csdes@ou.ac.lk) 
Keywords: Tomato, temperature stress, water stress, quality parameters

\section{Introduction}

Environmental stress is the primary cause of crop losses worldwide, reducing average yields for most major crops by more than 50\% (Boyer, 1982; Bray et al., 2000). The tropical vegetable production environment is a mixture of conditions that varies with season and region. Climatic changes will influence the severity of environmental stress imposed on vegetable crops. Moreover, increasing temperatures, reduced irrigation water availability, flooding, and salinity will be major limiting factors in sustaining and increasing vegetable productivity (Anon, 2005). Extreme climatic conditions will also negatively impact soil fertility and increase soil erosion. Thus, additional fertilizer application or improved nutrient-use efficiency of crops will be needed to maintain productivity or harness the potential for enhanced crop growth due to increased atmospheric $\mathrm{CO}_{2}$. The response of plants to environmental stresses depends on the plant developmental stage and the length and severity of the stress (Bray et al, 2002). Plants may respond similarly to avoid one or more stresses through morphological or biochemical mechanisms (Capiati et al., 2006). Environmental interactions may make the stress response of plants more complex or influence the degree of impact of climate change. Measures to adapt to these climate change-induced stresses are critical for sustainable tropical vegetable production.

Due to global warming, the temperatures are expected to increase over the present limits at a variable rate. Simultaneously, the water demand of the crops will also increase. Ghazala et al. (2010) computed the future water requirement of the crops generally grown in different climatic zones of Pakistan and tested three different enhancements $\left(1^{\circ} \mathrm{C}, 2^{\circ} \mathrm{C}\right.$ and $\left.3^{\circ} \mathrm{C}\right)$ in temperature. They found an average increase in crop water demand as $11 \%, 19 \%$, and $29 \%$ respectively. However, the crops need almost double the amount of water at $2{ }^{\circ} \mathrm{C}$ increase in temperatures at higher elevation agricultural plains of northern and western mountains. 
Tomato needs a controlled supply of water throughout the growing period for optimal quality and higher yield. Imposing water stress in vegetative and ripening stages means a certain amount of water may be saved. But tomatoes are very sensitive to water deficits during and immediately after transplanting, at flowering and during fruit development (Doorenbos and Kassam, 1979). Tomatoes consume water at a lower rate at the beginning of growth and then increase gradually until flowering, after which they reach maximum usage during the peak of fruit ripening. Water consumption remains constant until the onset of ripening after which, in determinate varieties, it decreases (Fisher and Nei, 1990). The approximate range of seasonal ET for tomatoes is $300 \mathrm{~mm}$ to $600 \mathrm{~mm}$. This seasonal value takes into account the crop characteristics, time of planting, and stage of crop development and general climatic conditions (Doorenbos and Kassam, 1979).

Heat stress (HS) is one of the most important constraints on crop production that adversely affects the vegetative and reproductive processes of tomato and ultimately reduces yield and fruit quality. High temperature condition strongly affected the vegetative and reproductive organs and tissues of tomato plants for all cultivars (Abdul-Baki, 1991).

Moreover, a number of explanations have been offered for the poor reproductive performance of tomatoes at high temperatures. These include reduced or abnormal pollen production, abnormal development of the female reproductive tissues, hormonal imbalances, low levels of carbohydrates, and lack of pollination (Bale et al, 1994). Abdalla and Verkerk (1968) have reported that high temperatures affect several physiological and biochemical processes of tomato plants, which finally effect on yield reduction.

Abdul-Baki, (1991) reported that the heat shock treatment has no positive effect on the vegetative and reproductive development and the hope that heat shock treatment would be beneficial for Tomato plants, particularly for the reproductive development at high temperatures was not fulfilled. This is in agreement with Abdul-baki (1991) who observed and suggested that heat shock on proteins have little to do with the reproductive stage. Also the plants in our experiments were well irrigated. Cutler et al., (1980) reported that Histamine proteins in soybean might accumulate under hot field 
conditions for drought plants but not for irrigated plants. Until now, the scientific information on the effect of environmental stresses on vegetables is limited. There is a need to do more research on how vegetable crops are affected by increased abiotic stresses as a direct potential threat from climate change (Capiati et al., 2006).

Therefore, this study was designed to identify the effect of simulated temperature and water stress on quality of fruits produced by tomato plants (var. Rajitha) to understand the effect of global warming.

\section{Methodology}

\section{Field Experiment}

The experiment was carried out in the two temperature regulated poly tunnels in order to mimic the global warming situations. Poly tunnels were installed at the Open University of Sri Lanka, Nawala, Nugegoda and the experiment was carried out during the period from 2012 to 2014 . Thermostats and ventilation fans were installed in each poly tunnel and the temperature was set for $32^{\circ} \mathrm{C}$ and $34^{\circ} \mathrm{C}$ as maximum temperatures. These temperatures were selected based on IPCC result on global climate (IPCC, 2007) and the HadCM3 predictions of Sri Lankan air temperature in 2050 for A2 scenario of IPCC (De Silva et al, 2007 and De Silva, 2006). When the temperature inside the poly tunnel increases above the maximum set temperature the ventilation fans start to operate automatically until the temperature is reduced to the maximum set temperature in the thermostat. The poly tunnel was made with polyvinyl chloride (PVC) sheet of 120 micron gauge to have more than 90\% transmittance of light and semi-circular elongated in shape with open space at the top only to facilitate the natural circulation of air. Temperature and relative humidity were measured continuously. The basic structure of the poly tunnel was fabricated with galvanized iron (GI) pipe and installed in the experimental field. Experiments were repeated five times in order to replicate the temperature and the tunnel effect.

\section{Water application}

Each pot (1' $\mathrm{x} 1^{\prime}$ in dimension) was filled with $5 \mathrm{~kg}$ of air dried reddish brown earth mixed with compost soil. Other recommended 
agronomic practices of DOA for Tomato (var.Rajitha) were followed. Two water regimes were imposed which were well-watered treatment at field capacity and water stress imposed by reducing the soil water content until $50 \%$ of the field capacity level.

Soil moisture was determined prior to each irrigation daily and daily rainfall and pan evaporation data were recorded. Soil bulk density was measured to calculate volumetric water content of soil. The upper limit (field capacity) and the lower limit (permanent wilting point) of the available soil moisture contents of volumetric basis were considered as $28 \%$ and $16 \%$ respectively.

Soil field capacity was calculated on soil dry weight basis. Water stress treatments were imposed when the plants were established at 2 weeks of age of the plants. Only the deficit amount of moisture was added to the root zone to attain field capacity. Before starting addition of water, tensiometer was fixed to the soil of the each pot polyethylene encircled root zone.

\section{Relative humidity (RH)}

Relative humidity was measured daily with $\mathrm{RH}$ meter to maintain the relative humidity changes indies the poly tunnel and the out side to keep the environmental condition uniform. But, there were no significant differences in $\mathrm{RH}$ observed in the inside and outside environment although elevated day time air temperatures in the poly tunnel resulted in higher partial pressure of water. This condition was maintained with the opening of the upper top which helped maintain the same water vapor concentration compared to the outside.

\section{Experimental Design}

The experiment was laid out in Split Plot experiment based on Complete Randomized Design (CRD) with ten replicates for the main plot treatment. Main plot included two different soil moisture conditions such as field capacity (no water stress) and $50 \%$ of the field capacity level (water stress) and sub plots contained 3 different temperature regimes such as $34^{\circ} \mathrm{C}$ maximum temperature poly tunnel, $32^{\circ} \mathrm{C}$ maximum temperature poly tunnel and ambient temperature at open space. 


\section{Estimating Qualitative Parameters of Tomato Fruits}

Five randomly selected ripe fruits (judged by appearance) from all plants within each plot were selected for analysis. After analysis of external qualities, fruit Juice was extracted for the chemical analysis. Juice of each fruit was extracted by dividing the fruit into halves and pressing them to pass through a $1 \mathrm{~mm}$ metallic sieve, facilitating removal of the fruit coat and the seeds. Data were collected in 7 day intervals.

\section{- Fruit's external color}

Immediately after harvesting, the tomato fruits were washed and wiped to dryness, and color measurements were performed on the opposite sides of the equatorial section of the fruit. Skin color was measured using a Minolta CR 300 Chroma portable colorimeter (Minolta Co., Osaka, Japan) with C illuminant. Fruit chromaticity was expressed in $L^{*}, a^{*}$, and $b^{*}$ color space coordinates (CIELAB; Figure 1). The colorimeter was calibrated with a white standard calibration plate $(\mathrm{Y}=93.9, \mathrm{x}=0.3134, \mathrm{y}=0.3208)$ before use. $L^{*}$ corresponds to a dark/light scale $(0=$ black, $100=$ white $)$ and represents the relative lightness of colors, being low for dark colors and high for light colors (Lancaster et al., 1997).

\section{Fruit shape}

Fruit length and fruit width were measured using marked plants each with 4 fruits at physiological maturation time. Fruit shape index was determined as below.

Fruitshapeindex $=\frac{\text { Averagefruitlength }}{\text { Diameter }}$

\section{- Fruit cracking}

After each harvesting, the total number of fruits and the number of fruits showing radial cracks larger and smaller than $2 \mathrm{~cm}$ were counted. At the same time fruits were classified according to their number of cracks. 


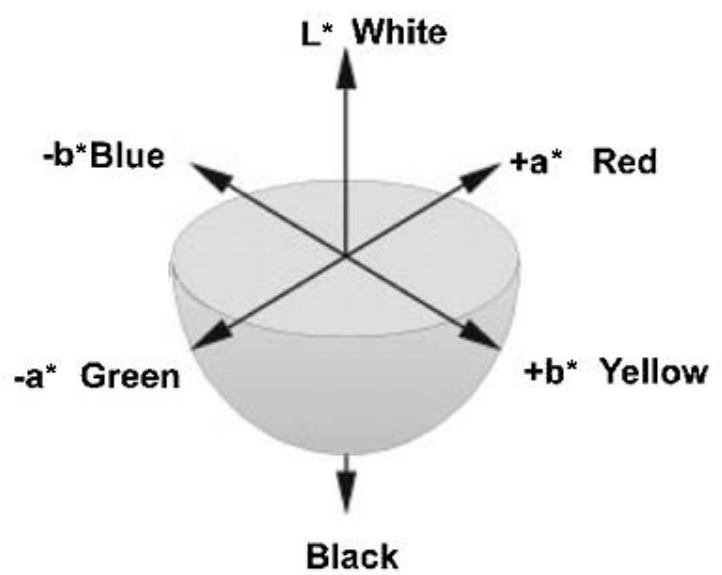

Figure 1. The CIELAB colour space system.

\section{- Dry matter content and moisture}

Dry matter content of fruits was analyzed using oven dry method (Kirk and Sawyer, 1990). Petri dishes were weighed and a $10 \mathrm{~g}$ of tomato flesh was taken using a grater and cut into smaller pieces in order to facilitate the drying process. Total weight of the fresh sample + Petri dish was taken immediately after placing the sample on the dish in order to avoid loss of water from it. Samples were dried in the oven with an air at $70^{\circ} \mathrm{C}$ until constant weigh was reached (around 4-6 hours). After the drying, the samples were weighed and noted the total weight of the dry sample + Petri dish (C) was noted. The percentage of dry matter was calculated by using the following formula.

Percentage dry matter $=\frac{(\mathrm{C}-\mathrm{A}) \times 100}{(\mathrm{~B}-\mathrm{A})}$

Where,

A $=$ Weight of Petri dish

$B=$ Total weight of fresh sample + Petri dish

$\mathrm{C}=$ Total weight of dry sample + Petri dish 


\section{- $\mathbf{p H}$}

Measurements of $\mathrm{pH}$ level were conducted on fresh juice samples after shaking vigorously. Bench $\mathrm{pH}$ Meter Model 510 was used for the measurements.

\section{- Total Soluble Solid}

Total soluble solids (TSS) was measured twice on juice from each tomato, using a digital refractometer Atago (ATAGO, Inc. Kirkland, WA, USA) and results were expressed as Brix value. From each fruit, two longitudinal slices (from stem end to calyx-end) were taken. The slice was squeezed longitudinally to get a mixture of juice from all regions. An equal number of drops from the prepared fruit juice was placed onto the refractometer prism plate. The reading on the prism scale was noted to one decimal place. After each test the prism plate was cleaned with water (distilled) and wiped with soft tissue to dry.

\section{- $\quad$ Titratable acidity}

Titratable acid of fruits was analyzed using the method of titration. The tomato fruits were washed, peeled, and cut into small pieces and pulp was prepared by using mixer blinder. A ratio of 2:1 (Pulp: Distilled water; w/v) was utilized in the extraction process. For estimating titratable acidity, $10 \mathrm{~g}$ of extracted juice was thoroughly mixed with $50 \mathrm{ml}$ of deionized distilled water. The mixture was then titrated by adding $0.1 \mathrm{~N} \mathrm{NaOH}$ until a $\mathrm{pH}$ of 8.1 was attained. The volume of the sodium hydroxide, added to the solution, was multiplied by a correction factor of 0.064 to estimate titratable acidity as percentage of citric acid (AOAC, 1986).

\section{- Sugar acid ratio}

The sugar/acid ratio contributes towards the fruit's characteristic flavor and is also an indicator of commercial and organoleptic ripeness. The following equation was used to calculate the sugar acid ratio.

$$
\text { The sugar acid ratio }=\frac{\text { "Brix Value }}{\text { Percentgae of acid }}
$$




\section{Statistical Analysis}

All extraction runs and analyses were carried out at least in duplicate and in randomized order with the mean values being reported. Analysis of variance (ANOVA) of the results was performed using General Linear Model procedure of SPSS (Software Version 19). Multiple comparison of means was carried out by LSD (Least Significant Difference) test at $\mathrm{P}=0.05$ and $\mathrm{P}=0.01$.

\section{Results and Discussion}

According to the growth and yield parameters such as plant height, fresh weight, number of fruit per plant and fruit yield of this study, there was a significant effect of individual stress of water and temperature and in combination (Gunawardena and De Silva, 2015). Therefore, the results of the Quality parameters are discussed in this paper. Ripening rate was inversely related to temperature and water stresses (Sanders et al, 1989). Tomato grown in ambient temperature reached fully ripened stage (3 Days after light-red ripeness stage) around 10-11 days. Fruits in the Tomato plants subjected to temperature and water stresses reached full redripeness stage about 2 day earlier than control of ambient temperature with no stress condition. There was no significant difference in time required to reach full-ripe stage between treatments. This observation means that the impact of stress condition on the tomato can promote fruit ripening. Temperature and water stresses can enhance ethylene production and it can affect the ripening of tomato, since ethylene is a major hormone coordinating ripening processes in fruits and vegetables.

Quality parameters like high soluble solid and sugar content, $\mathrm{pH}$ and fruit colour underline quality of yield. According to previous experience (Stevens and Rudich 1978) soil moisture content influenced some chemical and biological parameters of Tomato. Non water stress condition especially at the end of the growing cycle may lead to a significant reduction of solid soluble and sugar content and acidity. Also individual water stress did not influence fruit colour and $\mathrm{pH}$ significantly (Moore et al, 1958). This trial emphasized the different responses of individual water stress, individual temperature stress as well as combination stress condition. 


\section{Temperature and water stress on fruit quality parameters}

- Fruit colour

The statistical analysis showed that the average values for $L^{*}(\mathrm{P}<$ $0.05)$ and $a^{*}(\mathrm{P}<0.05)$ color parameters were significantly affected by temperature stress, but did not significantly affect water stress and interaction between them (Table 1). When averaged over growing location, the lightness factor $L^{*}$ of no water stress in ambient condition was significantly higher and the $A^{*}$ values were significantly lower when compared to the fruits growing under stress conditions.

Table 1. Fruit colour parameters

\begin{tabular}{|c|c|c|c|}
\hline Treatments & $\mathbf{L}$ & $\mathbf{A}$ & B \\
\hline $\begin{array}{l}\text { Ambient tem. No water } \\
\text { stress }\end{array}$ & $44.7 \pm 0.5 a$ & $26.6 \pm 0.6 a$ & $\begin{array}{l}29.5 \pm \\
0.7 \mathrm{a}\end{array}$ \\
\hline $\begin{array}{l}\text { Ambient tem. } 50 \% \text { water } \\
\text { stress }\end{array}$ & $44.8 \pm 0.5 a$ & $26.7 \pm 0.6 a$ & $\begin{array}{l}28.8 \pm \\
0.6 \mathrm{a}\end{array}$ \\
\hline $\begin{array}{l}32^{\circ} \mathrm{C} \text { maximum tem. No } \\
\text { water stress }\end{array}$ & $43.7 \pm 0.65 \mathrm{ab}$ & $\begin{array}{l}24.42 \pm 0.2 \mathrm{a} \\
\mathrm{b}\end{array}$ & $\begin{array}{l}27.9 \\
\pm 1.1 \mathrm{~b}\end{array}$ \\
\hline $\begin{array}{l}32^{\circ} \mathrm{C} \text { maximum tem. } \\
50 \% \text { water stress }\end{array}$ & $46.3 \pm 0.87 a$ & $\begin{array}{l}25.54 \pm 0.12 \\
\mathrm{a}\end{array}$ & $\begin{array}{l}26.8 \\
\pm 1.7 \mathrm{a} \\
\mathrm{b}\end{array}$ \\
\hline $\begin{array}{l}34^{\circ} \mathrm{C} \text { maximum tem. No } \\
\text { Water stress }\end{array}$ & $41.6 \pm 0.45 b$ & $\begin{array}{l}23.51 \pm 0.16 \\
b\end{array}$ & $\begin{array}{l}23.6 \\
\pm 2.1 \mathrm{~b}\end{array}$ \\
\hline $\begin{array}{l}34{ }^{\circ} \mathrm{C} \text { maximum tem. } \\
50 \% \text { Water stress }\end{array}$ & $41.4 \pm 0.67 b$ & $\begin{array}{l}22.64 \pm 0.19 \\
b\end{array}$ & $\begin{array}{l}22.5 \\
\pm 1.9 \mathrm{~b}\end{array}$ \\
\hline
\end{tabular}

Different letters indicate significant at the $0.01<\mathrm{P} \leq 0.05$ probability level.

\section{- Fruit shape}

Fruit shape is one of the most important physical properties and quality parameters of all agricultural produce. Shape of the tomato 
fruits witnessed significant variation with soil moisture condition (Table 2). Fruits of the no water stress treatments were more round in shape than those of imposed water stressed fruits. The lowest shape index (fruit length/diameter ratio) was observed in no water stress treatments. It means that no water stressed plants were able to produce more round shape fruits, whereas plants under temperature and water stress condition produced oval shaped fruits.

Table 2. Shape index of fruits

\begin{tabular}{lc}
\hline Treatments & Shape index \\
\hline Ambient tem. No water stress & $1.01 \pm 0.5 \mathbf{a}$ \\
\hline Ambient tem. 50\% water stress & $1.18 \pm 0.5 \mathbf{b}$ \\
\hline $32^{\circ} \mathrm{C}$ maximum tem. No water stress & $1.07 \pm 0.65 \mathbf{a}$ \\
\hline $32^{\circ} \mathrm{C}$ maximum tem. 50\% water stress & $1.19 \pm 0.87 \mathbf{b}$ \\
\hline $34^{\circ} \mathrm{C}$ maximum tem. No Water stress & $1.08 \pm 0.45 \mathbf{a}$ \\
\hline $34^{\circ} \mathrm{C}$ maximum tem. 50\% Water stress & $1.24 \pm 0.67 \mathbf{b}$ \\
\hline
\end{tabular}

Different letters indicates significant at the $0.01<\mathrm{P} \leq 0.05$ probability level

\section{- Fruit cracking}

Fruit cracking in Tomatoes like fleshy fruits can cause serious economic losses. Cracks reduce marketability and provide entry for insects and fungi, causing significant income loss in the fresh market and processing Tomato industries. There are many types of fruit cracking: longitudinal or burst cracking; ring or concentric cracking, crazing or rusting; lenticular cracking; and core failure (Figure 2). In this study, concentric fruit cracks were observed in all treatments except in no water stress condition under ambient environment. Total cracks level was $46 \%$ significantly higher $(\mathrm{p}=$ 
0.05) in $34^{\circ} \mathrm{C}$ maximum temperature treatments for both water stress and no water stress conditions. Under the green house condition, inside temperature goes beyond $25^{\circ} \mathrm{C}$ in many occasions. That may be lead to the diurnal stress for the plants growing in the green house. High temperatures in general and sudden high temperatures in mid afternoon in particular, caused red ripe tomato fruit to crack in the maximum $34^{\circ} \mathrm{C}$ poly tunnel. Raising fruit temperature dramatically increased the pressure exerted by the pulp on the skin and at the same time decreased skin stiffness and strength, increasing the incidence of splitting (Marr and Jirak 1990).

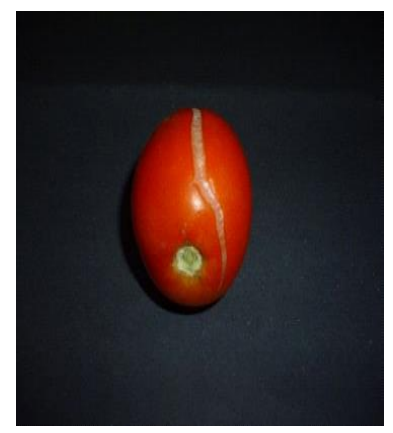

(a)

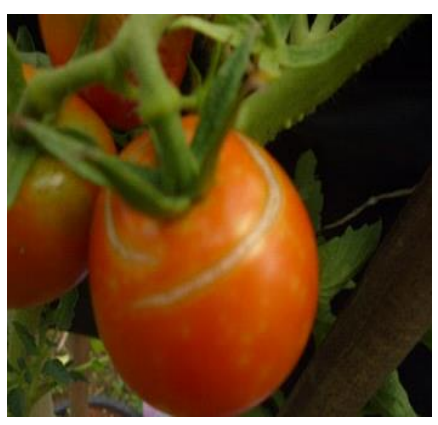

(b)

Figure 2. (a) Longitudinal and (b) concentric cracks

\section{- $\quad$ Fruit moisture content}

There were significant reductions in dry matter content at individual water stress compared to the other treatments. Individual water stress treatment had a highly significant $(\mathrm{p}=0.01)$ negative impact on fruit moisture content (Table 3). Similar individual temperature stress also leads to the reduction of the fruit moisture content but this is not statistically significant. Interaction effects of both stresses severely reduce the fruit moisture content and was significant at the 0.01 probability level. 
Table 3. Analysis of variance of temperature and water stress on qualitative parameters

\begin{tabular}{lccccc}
\hline Source of variations & df & $\begin{array}{c}\text { Moisture } \\
\%\end{array}$ & $\begin{array}{c}\text { Soluble Solid } \\
\text { (Brix) }\end{array}$ & $\mathrm{P}^{\mathrm{H}}$ & $\begin{array}{c}\text { Titrable } \\
\text { Acidity \% }\end{array}$ \\
\hline Main plot trt (WS) & 1 & $2346.125^{* *}$ & $57.537^{* *}$ & $0.261^{* *}$ & $1.194^{*}$ \\
Sub plot trt (TS) & 2 & 16.625 & $8.681^{* *}$ & $0.094^{* *}$ & $1.249^{*}$ \\
WS*TS & 2 & $37.625^{* *}$ & $1.017^{*}$ & 0.24 & 0.428 \\
Error & 12 & 5.208 & 0.202 & 0.08 & 399 \\
\hline
\end{tabular}

* indicates signific ant at the $0.01<\mathrm{P} \leq 0.05$ probability level; and ** indicates significant at the $\leq 0.01$ probability level

\section{- Soluble solids content (SSC)}

SSC of tested tomato ranged from 4.5 to $12.07{ }^{\circ}$ Brix and $34^{\circ} \mathrm{C}$ maximum temperature level combined with water stress showed a significant effect $(p>0.05)$ on the soluble solids $\left({ }^{\circ} \mathrm{Brix}\right)$ of tomato fruit with both water stress and no water stress treatment conditions. Both individual stresses had a highly significant $(\mathrm{P}=0.01)$ impact on the soluble solid content of the fruit. Moore et al. (1958) observed that low water stress resulted in maximum yield of tomato raw product, best viscosity and low soluble solids. In this study, high water stress caused lower yield, highest soluble solids, and poorer viscosity. Ambient temperature treatment yielded good marketable production with less soluble solids than high temperature treatments. This is attributed to the restricted water uptake into the fruit under stress, lower percentage of water in the fruit, and consequently higher solute concentration.

\section{- $\mathbf{p H}$}

In terms of $\mathrm{pH}$ (Table 3) no clear pattern emerged, except that no stress fruits tended to have higher $\mathrm{pH}$ and fruit with stresses showed lower $\mathrm{pH}$. According to that, individual water stress and high temperature effect had a highly significant effect $(P=0.01)$ on $\mathrm{pH}$ of fruits in this study (Table 3). Similarly, studies of the effect of individual water stress on tomato fruit $\mathrm{pH}$ have been inconsistent. For example Giardini et al., (1988) found a decrease in fruit $\mathrm{pH}$ under stress, while Sanders et al., (1989) found the opposite and 
Alvino et al., (1988) found no effect. As the overall flavor intensity of tomato fruits are highly related to $\mathrm{pH}$, acid level and soluble solids content, high sugars and high acids in the proper balance promote the desired flavor.

\section{- Total titrable acidity}

Total titratable acidity percentage of tomato at full-red ripeness stage ranged from 0.38 to 0.64 among the six treatments. Fruit had the different acidity levels depending on the individual stress effect and interaction effects of the stresses. Fruit treated of higher temperature with water stress had the highest TTA (0.64) and tomato treated at ambient temperature with no water stress had the lowest TTA (0.38 to 0.39). According to the analysis of variance, both individual stresses show significant influence of the acidity development at 0.05 probability level.

\section{- Sugar acid ratio}

The sugar/acid ratio was calculated on the basis percentage of each individual compound. According to the results of (Table 4) sugars as well as acid content were improved with stimulated stress. Therefore, highest sugar acid ration (20) was observed with $34^{\circ} \mathrm{C}$ maximum temperature with no water stress condition.

Sugar/acid ratio was calculated to estimate tomato flavour. Low acid content and high sugar content improve fruit quality (Stewart et al., 1977). The metabolism of cellular contents, important for the taste of fruit (for ex. sugars, organic acids, polysaccharides, pigments and aromatic components) changes significantly during the development of the fruits. Therefore, the care for the quality of fruit and yield by metabolic control of these substances during the growth period and during the development of fruits is of special importance. 
Table 4. Sugar acid ratio

\begin{tabular}{llll}
\hline Treatments & $\begin{array}{l}\text { Sugar } \\
\text { ('Brix) }\end{array}$ & Acid \% & $\begin{array}{l}\text { Sugar/acid } \\
\text { ratio }\end{array}$ \\
\hline $\begin{array}{l}\text { Ambient tem. No water } \\
\text { stress }\end{array}$ & $4.7 \pm \mathbf{0 . 6 9}$ & $0.38 \pm \mathbf{0 . 1 5 6}$ & $12.36 \pm \mathbf{1 . 5 b}$ \\
\hline $\begin{array}{l}\text { Ambient tem. 50\% water } \\
\text { stress }\end{array}$ & $5.6 \pm \mathbf{1 . 0 7}$ & $0.39 \pm \mathbf{0 . 1 6 7}$ & $14.35 \pm \mathbf{2 . 1 \mathbf { b }}$ \\
\hline $\begin{array}{l}\text { 32 }{ }^{\circ} \mathrm{C} \text { maximum tem. No } \\
\text { water stress }\end{array}$ & $6.7 \pm \mathbf{0 . 6 5}$ & $0.42 \pm \mathbf{0 . 2 0 3}$ & $15.95 \pm \mathbf{1 . 1 b}$ \\
\hline $\begin{array}{l}32^{\circ} \mathrm{C} \text { maximum tem. } \\
50 \% \text { water stress }\end{array}$ & $8.5 \pm \mathbf{0 . 8 7}$ & $0.54 \pm \mathbf{0 . 1 2 7}$ & $15.7 \pm \mathbf{1 . 7 b}$ \\
\hline $\begin{array}{l}\text { 34 }{ }^{\circ} \mathrm{C} \text { maximum tem. No } \\
\text { Water stress }\end{array}$ & $10.2 \pm \mathbf{0 . 4 5}$ & $0.51 \pm \mathbf{0 . 1 6 3}$ & $20 \pm \mathbf{2 . 1 a}$ \\
\hline $\begin{array}{l}\text { 34 }{ }^{\circ} \mathrm{C} \text { maximum tem. } \\
50 \% \text { Water stress }\end{array}$ & $12.4 \pm \mathbf{0 . 6 7}$ & $0.64 \pm \mathbf{0 . 1 9 2}$ & $\begin{array}{l}19.375 \pm \mathbf{1 . 9} \\
\mathbf{a}\end{array}$ \\
\hline
\end{tabular}

Different letters indicates significant at the $0.01<\mathrm{P} \leq 0.05$ probability Level.

\section{- Diseases}

During the first and third seasons tomato plants growing in the poly tunnel were attacked by the Mealy bug which spread very quickly for a few rows of the plants in high temperature poly tunnel (Figure 3). Mealy bugs caused a range of damage symptoms to tomato crops, adults and nymphs fed on the leaves and stems causing necrotic areas and reduced plant vigour. The pest also excreted excess sap (honeydew) on which black sooty moulds grew, which led to the reduction of fruit quality. Researchers have shown that temperature is probably the single most important environmental factor influencing insect behaviour, distribution, development, survival, and reproduction and believe that the effect of temperature on insects largely overwhelms the effects of other environmental 
factors (Bale et al., 2002). In general, it is a reasonable assumption that many insect pests have the potential to become more damaging as a result of high temperature or expected climate change. With global warming especially during the dry months, the growth of pests will accelerate, possibly leading to higher population growth. It has been estimated that with a $2^{\circ} \mathrm{C}$ temperature increase, insects might experience one to five additional life cycles per season (Adil et al., 2003).

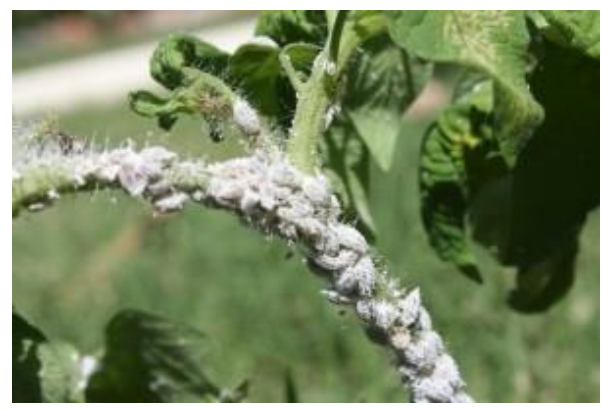

Figure 3. Mealy bug attach in Tomato

\section{Conclusions and Recommendations}

According to the results, the fruit colour is not in favourable marketable condition when the plants are exposed to temperature and water stress. The fruit shape was round in no water stress conditions and the stress conditions produced an oblong shape with a tip at the bottom. High market value is picked by round fruits than the oblong fruits. Temperature stress made the fruits crack and have low moisture content which led to disease attacks and low marketable value for such fruits. In this study high water stress caused lower yield, highest soluble solids, and poorer viscosity. With respect to $\mathrm{pH}$, no clear pattern emerged, except that no stress fruits tended to have higher $\mathrm{pH}$ and fruit with stresses showed lower $\mathrm{pH}$. Treatments exposed to higher temperature with water stress had the highest TTA (0.64) and the treatments at ambient temperature with no water stress had the lowest TTA (0.38 to 0.39). With regard to sugar acid ratio, highest sugar acid ration (20) was observed with $34^{\circ} \mathrm{C}$ maximum temperature with no water stress condition. Higher sugar acid ration is a good quality feature for 
tomato fruits for salads. Disease out break is heavier in high temperature stress conditions.

Therefore, Tomato variety Rajitha could not be a successful open field crop in the dry zone of Sri Lanka if temperature is increased due to global warming. But tomato could be cultivated under green houses by providing adequate water and required kind of soil temperature and management practices. But it will be an expensive venture if one were to calculate the energy used to maintain the green houses in optimum environmental conditions. This experiment should be repeated for other Tomato varieties as well. However, traditional tomato varieties in fact, like Goraka Thakkali may perform better in global warming situations. Producing varieties which perform better under high temperature and water stress may be better than modifying the environment.

\section{References}

Abdalla, A., \& Verderk, K. (1968). Growth, Flowering and fruit set of Tomato at high temperature. The Neth J Agric Sci 16, 71-76.

Abdul, B. (1991). Tolerance of Tomato cultivar and selected germ plasm to heat stress. Amer. Soc. Hort. Sci. 116(6) , 71-76.

Adil, H., Abdelmageeda, K., Grudab, N., \& Geyerb, B. (2003). Effect on high temperature and heat shock on Tomato. University of Khartoum, Department of Horticulture. Berlin: Institute for Horticulture Scince.

Alvino, A., Andria, R., and Zerbi, G. (1988). Fruit ripening of different tomato cultivars as influenced by irrigation regime and time of harvesting. Acta Hort. , 137-141.

https://doi.org/10.17660/ActaHortic.1988.228.14

Anon. (2005a). Food crop in chnaging climate. Royal socity discusstion meeting. U.K: Royal Socity.

AOAC. (1986). Official methods of analysis (Vol. 12th Edition). Washington DC USA: Association Of Analytical Chemist.

Bale, J., Masters, I., Hodkinson, C., Awmack, T., Bezemer, T., Brown, V., (1994). Vegetable crops: Horticulture. Islamabad: National Book Foundation. 
Boyer, J. (1982). Plant productivity and envirement. Scince, 218, 443-448. https://doi.org/10.1126/science.218.4571.443

Bray, E., Bailey, S., and Weretilnyk, E. (2002). Responses to abiotic stresses. Rockville: ASPP.

Capiati, D., Pais, S., \& Tellez-Inon, M. (2006). Wounding increases salt tolerance in tomato plants. Exp Bot, 2391-2400. https://doi.org/10.1093/jxb/erj212

De Silva, C. (2006). Spatial impacts of climatic change on water resource in Sri Lanka. 32nd WEDC international conference (pp. 314-318). Colombo, Sri Lanka: WEDC.

De Silva, C., Weatherhead, J., Knox, J., and Diaz, R. (2007). Predicting the impacts of climate change- A case study of paddy irrigation water requirments in Sri Lanka. Water Management, 93, 19-29.

https://doi.org/10.1016/j.agwat.2007.06.003

Doorenbos, J., and Kassam, A. (1979). Yield response to water - FAO irrigation and drainge paper 33. Rome: FAO.

Fisher, H., and Nei, P. (1990). Deficit drip irrigation of market tomatoes on three soil types. Act. Hort, 278, 797-806. https://doi.org/10.17660/ActaHortic.1990.278.79

Ghazala, N., and Mahmood, A. (2009). Water requirement for wheat crop in Pakistan. Pakistan Journal of Meteorology, 6 (11), 8996.

Giardini, L., Giovanardi, R., and Borin, M. (1988). Water consumption and yield response of tomato in relation to water availability at different soil depths. Acta Hort, 228, 119 126. https://doi.org/10.17660/ActaHortic.1988.228.12

Gunawardena, M.D.M. and C.S De Silva(2015). Impact of induced temperature and water stress on vegetative and reproductive parameters of Tomato (Lycopersicum esculantum) variety Rajitha. OUSL Journal Vol 8 (19-38).

https://doi.org/10.4038/ouslj.v8i0.7316

IPCC. (2007). Fourth Assessment Report of the Intergovernmental Ppanel for Climate Change. New York: Cambridge University Press. 
Kirk, R., and Sawyer, R. (1985). Pearsons composition and analysis of foods . London, U.K.: Longman Group

Lancaster, J., Lisater, C., Reay, P., \& Triggs, C. (1997). Influence of pigment composition on skin colour in a wide range of fruit and vegetable. Amer Hort Sci, 122, 594-598.

Marr, C., \& Jirak, M. (1990). Holding Tomato transplants in plug trays. HortScince, 25, 173-176.

Moore, J., Kattan, A., \& Fleming, J. (1958). Effect of supplementary Irrigation, spacing and fertility on yield and quality of processing tomatoes. American Society for Horticulture Science (pp. 356-368). New York: ASHS.

Sanders, D., Howell, T., Hile, L., Hodges, L., Meedk, D., \& Phene, C. (1989). Yield and quality of processing tomatoes in response to irrigation rate and scedule. Hort.Sci., 114, 904-908.

Stevens, M., \& Rudich, J. (1978). Genetic potential for overcoming physiological limitaions on adaptability yield and quality of tomato. Horticultural Science, 13, 673-678.

Stewart, C., Bogess, D., Aspinall, D., \& Paleg, L. (1977). Inhibition of proline oxidation by water stress . Plant physiology, 930-932. https://doi.org/10.1104/pp.59.5.930

Received: 14-03-2016 Revised: 26-09-2016 Accepted: 04-10-2016 
